九州大学学術情報リポジトリ

Kyushu University Institutional Repository

\title{
Effect of Essential Amino Acid Deficiencies on the Liver Lipids of Rats
}

Maeda, Hideo

Laboratory of Nutrition Chemistry, Faculty of Agriculture, Kyushu University

Sugano, Michihiro

Laboratory of Nutrition Chemistry, Faculty of Agriculture, Kyushu University

Wada, Masafuto

Laboratory of Nutrition Chemistry, Faculty of Agriculture, Kyushu University

https://doi.org/10.5109/22839

出版情報：九州大学大学院農学研究院紀要. 17 (3/4)，pp.303-311，1973-10. Kyushu University バージョン：

権利関係 : 


\title{
Effect of Essential Amino Acid Deficiencies on the Liver Lipids of Rats
}

\author{
Hideo Maeda, Michihiro Sugaho and Masafuto Wada \\ Laboratory of Nutrition Chemistry, Faculty of Agriculture, \\ Kyushu University, Fukuoka
}

(Received June 19, 1973)

\begin{abstract}
The liver lipids of rats fed on the diets deficient in essential amino acid (EAA)* were compared with those of the corresponding pair-fed controls. The concentration and composition of hepatic lipids are modified specifically according to each EAA deficiency. In general, feeding the diets deficient in EAA resulted in the decrease in the concentration of hepatic phospholipid. This was most remarkable in Lys, Val or Leu (and perhaps Phe or Trp) deficiency. The decrease in the concentration of hepatic phosphatidylethanolamine (PE) was more predominant than that of phosphatidylcholine (PC). The concentration of triglyceride increased in rats fed on the diets devoid of each EAA except Val. The response of cholesterol concentration was scattering. In the liver and its microsomal PC percentage of linoleate increased in Ileu, Thr, Met or Leu (and Phe) deficiency and that of arachidonate decreased in Met, Leu or Val (Phe) deficiency, respectively. Consequently, the ratio of arachidonate to linoleate reduced in Thr, Ileu or Met deficiency. These observations, together with those demonstrated previously, indicate that the quantity and the quality of dietary protein significantly influence on the metabolism of fatty acids, particularly linoleate and arachidonate.
\end{abstract}

\section{INTRODUCTION}

Administration of a low protein diet to rat results in changes in the concentration as well as the composition of hepatic phospholipids. The concentration of phospholipids decreases and percentage of linoleate increases at the expense of arachidonate in PC. A close relationship between the extent of desaturation of linoleate and the dietary protein levels has been reported (Maeda et al., 1973).

Obviously, protein nutrition should be understood not only at the quantitative but qualitative standpoints. Dietary deficiency (Hall et al., 1952) and imbalance (Sidransky and Farber, 1958) of EAA produce accumulation of liver lipids. As to the mechanism of the fatty infiltration, Yoshida and Harper (1960) indicated that the increased hepatic lipogenesis appeared to be apparently responsible for the production of fatty liver due to amino acid imbalance. Lyman et al. (1950) and Wilfred and Sekhara (1969) obtained evidence supporting that damage to

* Following abbreviations are used in this paper. EAA: essential amino acid, PC: phosphatidylcholine, PE : phosphatidylethanolamine, SPH : sphingomyelin, LPC :lysophosphatidylcholine, TG : triglyceride, FFA : free fatty acid 
lipoprotein synthesis in the liver, hence depression of release of the fatty components to blood stream, was not the important factor functioning to the accumulation of hepatic lipids.

By virtue of the tissue or cellular specificity in the fatty acid composition and of the molecular structure of the glycerides, each fatty acid appears to be metabolized very specifically (Hanahan and Blomstrand, 1956, Land, 1958). Thus, analyses of the fatty components in tissues of animals are of useful approach to the determination of these specificities. Only partial, but not systematic, information has been available on this problem (Sidransky and Virney, 1964).

This communication deals with the effect of EAA deficiencies on the concentration and composition of lipid components in rat liver and its subcellular fractions with special emphasis to those of phospholipids.

\section{MATERIALS AND METHODS}

\section{Animals and diets}

Male rats of a Wistar strain were housed in individual cage in an airconditioned room at 22-24 "C. The composition of the experimental diet is shown in Table 1. The amino acid mixture according to Rama Rao et al. (1961) was used. One group of the animals was fed on the diets lacking one EAA and the other was pair-fed on the complete diet. Omitted EAA was replaced by the same amount of glutamic acid. The present paper was composed of three separate experiments.

Table 1. Composition of basal diets.

\begin{tabular}{l|c}
\hline Components & $\%$ \\
\hline Sucrose & 70.85 \\
Amino acid mixture & 15.0 \\
Corn oil & 5.0 \\
Mineral mixture & 4.0 \\
Vitamin mixture & 1.0 \\
Choline chloride & 0.15 \\
Cellulose & $4: 0$ \\
\hline
\end{tabular}

1) Amino acid mixture according to Rama Rao (1961).

2) Contains the following percentages of fatty acids; $14: 0 ; 0.2,16: 0 ; 9.6,16: 1 ; 0.6,18: 0 ; 1.8,18: 1 ; 25.6$, $18: 2 ; 61.6,18: 3 ; 0.6$.

3) Obtained from the Tanabe Amino Acid Research Foundation.

4) Vitamin A 2400IU, vitamin $\mathrm{D}_{2} 2001 \mathrm{U}$ and vitamin E $10 \mathrm{mg}$ per $100 \mathrm{~g}$ diet were added to the mixture.

\section{Lipid analysis}

The rats were killed by decapitation 2 weeks after the feeding and the livers were quickly removed. Liver microsomes and mitochondria were fractionated according to Schneider and Hogeboom (1950) in an ice cold solution of $0.25 \mathrm{M}$ sucrose containing $0.001 \mathrm{M}$ EDTA. Lipids were extracted according to Folch et al. (1957). Total lipids, cholesterol and lipid phosphorus were determined by the method of Bragdon(1960), Sperry and Webb (1950) and Gomori 
(1942), respectively. The distribution of the phospholipid components was determined after separating them by thin-layer chromatography (TLC) (Rouser et al., 1966). Triglyceride content was calculated by subtracting phospholipid and cholesterol from total lipids. Fractionation of lipids by TLC and determination of fatty acid composition by gas-liquid chromatography were performed as described elsewhere (Sugano et al., 1969).

\section{RESULTS}

\section{Food intake and growth}

Table 2 shows that daily food intake was the minimum (4.8 g) in Ileu deficiency, though the differences of initial body weights of rats used in each experiment should be taken into consideration. The animals in Lys or Trp deficiency ingested above $8 \mathrm{~g}$ daily and this may indicate that the requirement of these two EAA for growth diminishes accompanying maturity of rats. When compared with the pair-fed controls, the loss of body weight was remarkable in Thr or Ileu (and Phe or Trp) deficiency.

Table 2. Body weight and food intake.a)

\begin{tabular}{|c|c|c|c|c|c|c|}
\hline \multirow{4}{*}{$\begin{array}{c}\text { Expt. } \\
\text { no. }\end{array}$} & \multirow{2}{*}{\multicolumn{2}{|c|}{ Diets }} & \multicolumn{2}{|c|}{ Body weight (g) } & \multirow{2}{*}{$\begin{array}{l}\text { Changes of } \\
\text { body weight } \\
\text { (g/2 weeks) }\end{array}$} & \multirow{2}{*}{$\begin{array}{l}\text { Average of } \\
\text { food intake } \\
\text { (g/day) }\end{array}$} \\
\hline & & & Initial & Final & & \\
\hline & $\begin{array}{l}\text { Thr deficient } \\
\text { Pair }\end{array}$ & $\begin{array}{l}(4) \\
(4)\end{array}$ & $\begin{array}{l}144 \pm 10 \\
142 \pm 7\end{array}$ & $\begin{array}{l}109 \pm 5 \\
145 \pm 8\end{array}$ & $\begin{array}{l}-35 \\
+3\end{array}$ & $\begin{array}{l}6.7 \\
6.7\end{array}$ \\
\hline & $\begin{array}{l}\text { Ileu deficient } \\
\text { Pair }\end{array}$ & $\begin{array}{l}(4) \\
(4)\end{array}$ & $\begin{array}{l}141 \pm \quad 6 \\
141 \pm 6 \\
\end{array}$ & $\begin{array}{r}92 \pm 9 \\
128 \pm 5 \\
\end{array}$ & $\begin{array}{l}-49 \\
-13 \\
\end{array}$ & $\begin{array}{l}4.8 \\
4.8 \\
\end{array}$ \\
\hline \multirow{2}{*}{2} & $\begin{array}{l}\text { Met deficient } \\
\text { Pair }\end{array}$ & (4) & $\begin{array}{l}165 \pm 2 \\
161 \pm 4\end{array}$ & $\begin{array}{l}138 \pm 1 \\
135 \pm 3\end{array}$ & \multirow[t]{2}{*}{07} & $\begin{array}{l}7.3 \\
7.3\end{array}$ \\
\hline & $\begin{array}{l}\text { Lys deficient } \\
\text { Pair }\end{array}$ & $\begin{array}{l}(4) \\
(4) \\
\end{array}$ & $\begin{array}{l}164 \pm 4 \\
159 \pm 3 \\
\end{array}$ & $\begin{array}{l}139 \pm 4 \\
135 \pm 3 \\
\end{array}$ & & $\begin{array}{l}8.2 \\
8.2 \\
\end{array}$ \\
\hline \multirow{4}{*}{3} & $\begin{array}{l}\text { Leu deficient } \\
\text { Pair }\end{array}$ & $\begin{array}{l}(3) \\
(3)\end{array}$ & $\begin{array}{l}200 \pm 20 \\
199 \pm 21\end{array}$ & $\begin{array}{l}165 \pm 17 \\
164 \pm 15\end{array}$ & $\begin{array}{l}-35 \\
-35\end{array}$ & $\begin{array}{l}7.3 \\
7.3\end{array}$ \\
\hline & $\begin{array}{l}\text { Val deficient } \\
\text { Pair }\end{array}$ & $\begin{array}{l}(3) \\
(3)\end{array}$ & $\begin{array}{l}198 \pm 23 \\
194 \pm 22\end{array}$ & $\begin{array}{l}154 \pm 18 \\
146 \pm 15\end{array}$ & $\begin{array}{l}-44 \\
-48\end{array}$ & $\begin{array}{l}6.4 \\
6.4\end{array}$ \\
\hline & $\begin{array}{l}\text { Phe deficient } \\
\text { Pair }\end{array}$ & $\begin{array}{l}(3) \\
(2)\end{array}$ & $192 \underset{183}{ \pm} 25$ & $154 \underset{150}{ \pm} 16$ & $\begin{array}{l}-48 \\
-33\end{array}$ & $\begin{array}{l}7.1 \\
7.1\end{array}$ \\
\hline & $\begin{array}{l}\text { Trp deficient } \\
\text { Pair }\end{array}$ & $\begin{array}{l}(3) \\
(2)\end{array}$ & $189 \underset{181}{ \pm} 27$ & $157 \underset{166}{ \pm} 23$ & $\begin{array}{l}-32 \\
-15\end{array}$ & $\begin{array}{l}8.7 \\
8.7\end{array}$ \\
\hline
\end{tabular}

a) Values are the mean $\pm \mathrm{SE}$. Figures in parentheses represent the number of rats.

\section{Hepatic lipid components}

As shown in Table 3 , the relative liver weight was apparently similar between the deficient and control rats, except in Thr or Ileu deficiency where the weight considerably decreased.

Hepatic total lipids tended to increase in rats fed Thr or Ileu (and Phe) deficient diets and to decrease in Leu or Val deficiency. On feeding the diets 


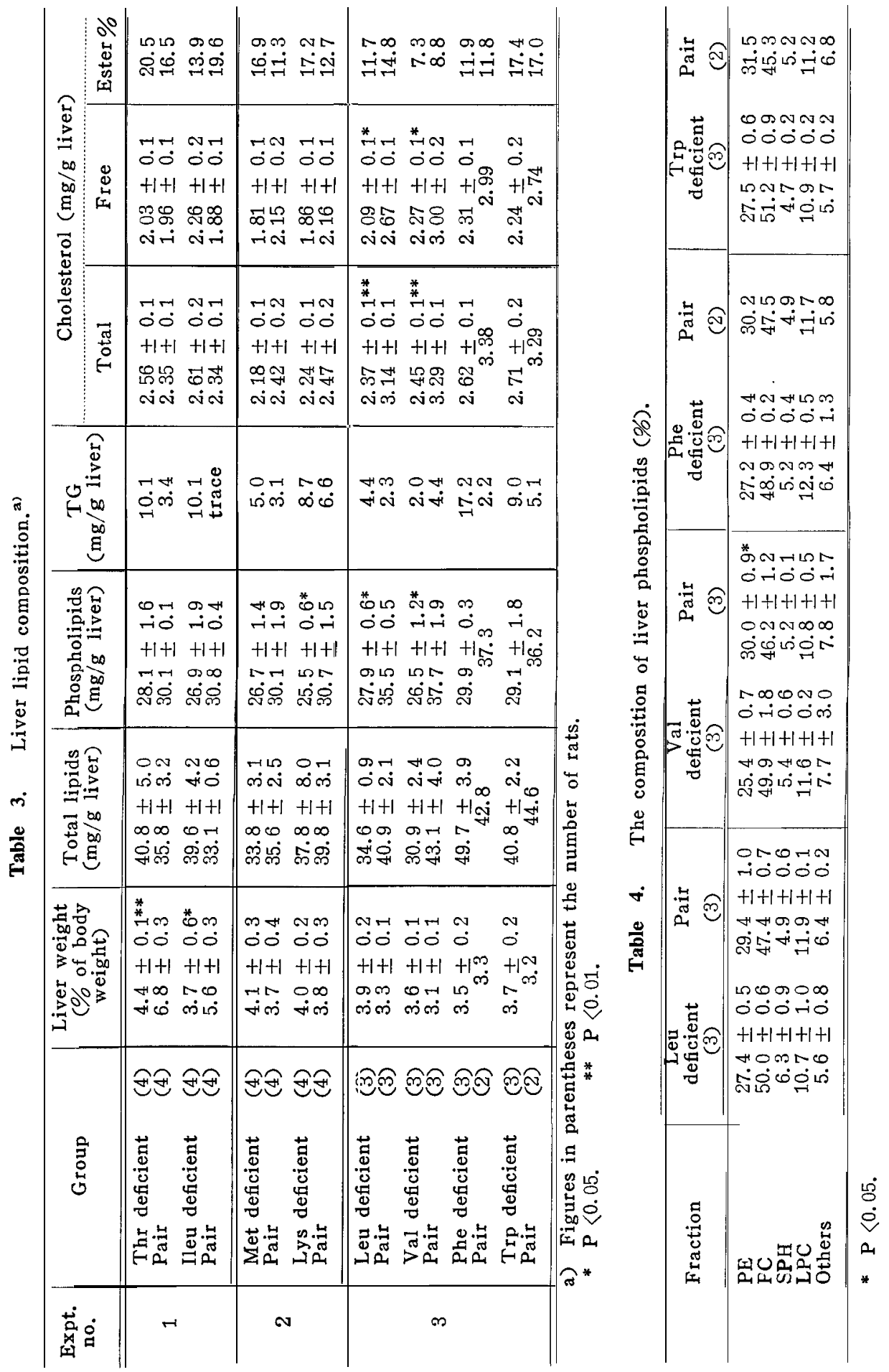


Table 5. Fatty acid composition of liver phosphatidylcholine.

\begin{tabular}{|c|c|c|c|c|c|c|c|c|c|}
\hline \multirow{2}{*}{$\begin{array}{c}\text { Expt. } \\
\text { no. }\end{array}$} & \multirow{2}{*}{\multicolumn{2}{|c|}{ Group }} & \multicolumn{5}{|c|}{ Fatty acids (wt. \%) } & \multirow[b]{2}{*}{$20: 4$} & \multirow[b]{2}{*}{$22: 6$} \\
\hline & & & $16: 0$ & $16: 1$ & $18: 0$ & $18: 1$ & $18: 2$ & & \\
\hline \multirow{2}{*}{1} & $\begin{array}{l}\text { Thr deficient } \\
\text { Pair }\end{array}$ & $\begin{array}{l}\text { (4) } \\
\text { (4) }\end{array}$ & $\begin{array}{l}29.3 \pm 0.9 \\
31.5 \pm 0.9\end{array}$ & $\begin{array}{l}2.1 \pm 0.3 \\
2.9 \pm 0.4\end{array}$ & $\begin{array}{l}18.1 \pm 1.0 \\
17.0 \pm 1.2\end{array}$ & $\begin{array}{l}10.1 \pm 0.5 \\
10.7 \pm 0.7\end{array}$ & $\begin{array}{l}15.1 \pm 0.6 \\
13.5 \pm 0.5\end{array}$ & $\begin{array}{l}19.5 \pm 0.6 \\
20.2 \pm 1.0\end{array}$ & $\begin{array}{l}3.5 \pm 0.1 * * \\
2.0 \pm 0.3\end{array}$ \\
\hline & $\begin{array}{l}\text { Ileu deficient } \\
\text { Pair }\end{array}$ & $\begin{array}{l}(4) \\
(4)\end{array}$ & $\begin{array}{l}26.7 \pm 2.3 \\
29.3 \pm 1.0\end{array}$ & $\begin{array}{l}2.8 \pm 0.5^{*} \\
4.6 \pm 0.4\end{array}$ & $\begin{array}{l}18.8 \pm 1.5 \\
15.6 \pm 1.0\end{array}$ & $\begin{aligned} 8.9 & \pm 0.5^{* *} \\
13.7 & \pm 0.9\end{aligned}$ & $\begin{array}{l}17.3 \pm 1.5^{*} \\
12.8 \pm 0.7\end{array}$ & $\begin{array}{l}18.7 \pm 3.2 \\
18.7 \pm 0.5\end{array}$ & $\begin{array}{l}4.5 \pm 0.7^{*} \\
2.3 \pm 0.3\end{array}$ \\
\hline \multirow[t]{2}{*}{2} & $\begin{array}{l}\text { Met deficient } \\
\text { Pair }\end{array}$ & $\begin{array}{l}(4) \\
(4)\end{array}$ & $\begin{array}{l}25.3 \pm 2.4 \\
22.6 \pm 2.1\end{array}$ & $\begin{array}{l}2.6 \pm 0.3 \\
2.2 \pm 0.2\end{array}$ & $\begin{array}{l}15.6 \pm 1.0 \\
16.1 \pm 0.3\end{array}$ & $\begin{array}{r}10.9 \pm 1.0 \\
8.6 \pm 0.3\end{array}$ & $\begin{array}{l}16.0 \pm 0.5 \\
14.6 \pm 0.7\end{array}$ & $\begin{array}{l}23.2 \pm 1.6^{*} \\
28.2 \pm 0.6\end{array}$ & $\begin{array}{l}4.0 \pm 0.5 \\
6.2 \pm 1.0\end{array}$ \\
\hline & $\begin{array}{l}\text { Lys deficient } \\
\text { Pair }\end{array}$ & $\begin{array}{l}(4) \\
(4)\end{array}$ & $\begin{array}{l}24.2 \pm 1.5 \\
24.1 \pm 0.3\end{array}$ & $\begin{array}{l}2.1 \pm 0.3 \\
2.1 \pm 0.1\end{array}$ & $\begin{array}{l}18.6 \pm 1.1 \\
17.5 \pm 0.7\end{array}$ & $\begin{array}{l}8.3 \pm 0.8 \\
8.7 \pm 0.7\end{array}$ & $\begin{array}{l}11.9 \pm 1.6 \\
12.6 \pm 0.6\end{array}$ & $\begin{array}{l}27.8 \pm 2.0 \\
27.0 \pm 1.0\end{array}$ & $\begin{array}{l}5.3 \pm 0.5 \\
6.1 \pm 0.5\end{array}$ \\
\hline \multirow{4}{*}{3} & $\begin{array}{l}\text { Leu deficient } \\
\text { Pair }\end{array}$ & $\begin{array}{l}(3) \\
(3)\end{array}$ & $\begin{array}{l}23.1 \pm 0.4 \\
22.8 \pm 1.3\end{array}$ & $\begin{array}{l}2.1 \pm 0.3 \\
2.4 \pm 0.4\end{array}$ & $\begin{array}{l}19.8 \pm 0.6 \\
16.4 \pm 1.1\end{array}$ & $\begin{array}{r}9.5 \pm 0.3 \\
11.1 \pm 0.6\end{array}$ & $\begin{array}{l}14.9 \pm 0.3 \\
13.9 \pm 0.5\end{array}$ & $\begin{array}{l}24.4 \pm 1.0^{*} \\
28.7 \pm 1.1\end{array}$ & $\begin{array}{l}4.6 \pm 0.3 \\
3.4 \pm 1.2\end{array}$ \\
\hline & $\begin{array}{l}\text { Val deficient } \\
\text { Pair }\end{array}$ & $\begin{array}{l}\text { (3) } \\
\text { (3) }\end{array}$ & $\begin{array}{l}26.1 \pm 0.4^{* *} \\
22.9 \pm 0.3\end{array}$ & $\begin{array}{l}2.4 \pm 0.4 \\
2.5 \pm 0.2\end{array}$ & $\begin{array}{l}18.0 \pm 1.2 \\
17.2 \pm 0.3\end{array}$ & $\begin{array}{r}9.2 \pm 0.3 \\
11.1 \pm 0.4\end{array}$ & $\begin{array}{l}12.7 \pm 1.0 \\
13.3 \pm 0.8\end{array}$ & $\begin{array}{l}25.5 \pm 0.5^{* *} \\
28.5 \pm 0.1\end{array}$ & $\begin{array}{l}4.7 \pm 0.3^{*} \\
3.1 \pm 0.3\end{array}$ \\
\hline & $\begin{array}{l}\text { Phe deficient } \\
\text { Pair }\end{array}$ & $\begin{array}{l}(3) \\
(2)\end{array}$ & $24.0 \underset{23.2}{ \pm 0.6}$ & $2.2 \underset{2.5}{ \pm} 0.4$ & $\begin{array}{c}19.6 \pm 0.7 \\
16.9\end{array}$ & $10.7 \underset{10.4}{ \pm} 3.4$ & $16.6{\underset{13.6}{ \pm}}^{0.8}$ & $22.0 \underset{28.7}{ \pm} 0.6$ & $3.3_{3.5}^{ \pm} 0.1$ \\
\hline & $\begin{array}{l}\text { Trp deficient } \\
\text { Pair }\end{array}$ & $\begin{array}{l}\text { (3) } \\
\text { (2) }\end{array}$ & $24.0 \underset{23.4}{ \pm} 1.0$ & $1.7 \underset{2.4}{ \pm} 0.3$ & $\begin{array}{c}21.9 \pm 0.9 \\
19.8\end{array}$ & $9.3 \underset{8.7}{ \pm} 1.0$ & $10.1 \underset{12.6}{ \pm} 0.2$ & $27.0 \pm \frac{ \pm}{30.0} 1.2$ & $4.8 \underset{2.0}{ \pm} 0.2$ \\
\hline
\end{tabular}

* $\mathrm{P}<0.05$.

$* * \mathrm{P}<0.01$. 
deficient in EAA resulted in general in the decrease of phospholipids, this being particularly remarkable in Lys, Leu or Val (and perhaps Phe or Trp) deficiency. In these groups of rats the decrease in the proportion of $\mathrm{PE}$ and thus the increase in that of PC was generally observed (Table 4). However, the net amounts of $\mathrm{PC}$ in whole liver decreased in these deficient groups.

The amount of TG obtained by calculation increased in each EAA deliciency except for Val and the extent of accumulation was remarkable in the rats deficient in Thr or Ileu (and perhaps Phe or Trp). An unusual low concentration of TG in the controls can be ascribed to the limited quantity of food ingested. The concentration of cholesterol decreased in Leu or Val (and Phe) deficency and this was mainly due to the decrease of the free form.

\section{Fatty acid composition}

Hepatic PC : The fatty acid composition was altered specifically according to each deficient EAA and was much predominant with the polyunsaturated acids (Table 5). Met, Leu or Val (and Phe) deficiency caused the decreases in percentage of arachidonate. In some deficient groups docosahexaenoate increased. In addition to these changes oleate decreased and linoleate increased in Ileu deficiency, and palmitate increased in Val deficiency.

Microsomal PC : The fatty acid composition of microsomal PC was similarly modified as was in the whole liver PC. The relative ratio of major fatty acids is summarized in Table 6. The ratio of palmitoleate to palmitate decreased in Thr or Ileu deficiency and that of oleate to stearate decerased only in Ileu deficiency. The ratio of arachidonate to linoleate decreased in Thr, Ileu or Met deficiency, this being mainly due to the increase in linoleate with concomitant decrease in arachidonate. Although similar changes in the ratio of the polyunsaturated acid were observed in rats fed on diets devoid of Leu or Phe, there was limitation in evaluating the results because these were determined on the pooled samples.

The ratio of arachidonate to linoleate also decreased, but rather to the lesser degree compared with that of microsomal PC, in the mitochondria from Ileu, Met or Leu deficiency (Table 7). On the contrary, the ratio tended to increase in mitochondrial PC of Lys (and Trp) deficiency and in microsomal PC of Trp deficiency. These results may be related to the amounts of food intake (cf. Table 2).

\section{DISCUSSION}

There has been considerable information about the morphological and compositional changes in the liver of rats fed on diets deficient or imbalanced in EAA. Accumulation of hepatic lipids in rats fed on diets devoid of EAA has been reported (Sidransky and Farber, 1958; Lyman et al., 1964). Imbalance in dietary amino acids causes enhancement of lipogenesis (Yoshida and Harper, 1960) and the increase in hepatic TG (Ogura et al., 1965). These observations support the view that the effect of dietary protein on the hepatic lipids should be examined at the quantitative as well as qualitative standpoints. 
Table 6. The ratio of fatty acids of liver microsomal phosphatidylcholine.

\begin{tabular}{|c|c|c|c|c|c|}
\hline \multirow{3}{*}{$\begin{array}{c}\text { Expt } \\
\text { no. }\end{array}$} & \multirow{2}{*}{\multicolumn{2}{|c|}{ Group }} & \multirow{3}{*}{$\begin{array}{c}16: 1 / 16: 0 \\
\mathbf{0 . 0 6 5 \pm 0 . 0 0 1 *} \\
\mathbf{0 . 0 8 0 \pm 0 . 0 0 1}\end{array}$} & \multirow{2}{*}{$18: 1 / 18: 0$} & \multirow{3}{*}{ 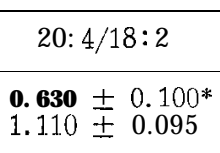 } \\
\hline & & & & & \\
\hline & $\begin{array}{l}\text { Thr deficient } \\
\text { Pair }\end{array}$ & $\begin{array}{l}(4) \\
(4)\end{array}$ & & $\begin{array}{l}\mathbf{0 . 6 1 3} \pm 0.033 \\
0.601 \pm 0.090\end{array}$ & \\
\hline 1 & $\begin{array}{l}\text { Ileu deficient } \\
\text { Pair }\end{array}$ & $\begin{array}{l}\text { (4) } \\
\text { (4) }\end{array}$ & $\begin{array}{l}0.074 \pm 0.014 * \\
\mathbf{0 . 1 2 9} \pm \mathbf{0 . 0 0 6}\end{array}$ & $\begin{array}{l}\mathbf{0 . 4 6 4} \pm 0.051 * \\
0.843 \pm \mathbf{0 . 0 1 7}\end{array}$ & $\begin{array}{l}0.650 \pm 0.100 " \\
1.126 \pm 0.130\end{array}$ \\
\hline \multirow{2}{*}{2} & $\begin{array}{l}\text { Met deficient } \\
\text { Pair }\end{array}$ & $\begin{array}{l}(4) \\
(4)\end{array}$ & $\begin{array}{l}0.117 \pm \mathbf{0 . 0 2 8} \\
\mathbf{0 . 0 7 6} \pm \mathbf{0 . 0 0 4}\end{array}$ & $\begin{array}{l}1.036 \pm 0.179 \\
0.638 \pm 0.027\end{array}$ & $\begin{array}{l}\mathbf{0 . 7 2 6} \pm \mathbf{0 . 1 1 5 "} \\
1.220 \pm \mathbf{0 . 0 8 9}\end{array}$ \\
\hline & $\begin{array}{l}\text { Lys deficient } \\
\text { Pair }\end{array}$ & $\begin{array}{l}(4) \\
(4)\end{array}$ & $\begin{array}{l}0.115 \pm 0.006^{*} \\
0.070 \pm 0.008\end{array}$ & $\begin{array}{l}0.610 \pm 0.062 \\
0.593 \pm 0.200 \\
\end{array}$ & $\begin{array}{l}1.458 \pm 0.147 \\
1.470 \pm 0.079 \\
\end{array}$ \\
\hline \multirow{4}{*}{3} & $\begin{array}{l}\text { Leu deficient } \\
\text { Pair }\end{array}$ & $\begin{array}{l}\text { (3) } \\
\text { (3) }\end{array}$ & $\begin{array}{l}0.097 \\
0.103\end{array}$ & $\begin{array}{l}0.466 \\
0.597\end{array}$ & $\begin{array}{l}1.68 \\
2.13\end{array}$ \\
\hline & $\begin{array}{l}\text { Val deficient } \\
\text { Pair }\end{array}$ & $\begin{array}{l}\text { (3) } \\
\text { (3) }\end{array}$ & $\begin{array}{l}0.102 \\
0.099\end{array}$ & $\begin{array}{l}0.485 \\
0.6^{\prime} 6\end{array}$ & $\begin{array}{l}2.12 \\
2.01\end{array}$ \\
\hline & $\begin{array}{l}\text { Phe deficient } \\
\text { Pair }\end{array}$ & $\begin{array}{l}(3) \\
(2)\end{array}$ & $\begin{array}{l}0.093 \\
0.113\end{array}$ & $\begin{array}{l}0.483 \\
0.615\end{array}$ & $\begin{array}{l}1.51 \\
2.01\end{array}$ \\
\hline & $\begin{array}{l}\text { Trp deficient } \\
\text { Pair }\end{array}$ & $\begin{array}{l}(3) \\
(2)\end{array}$ & $\begin{array}{l}0.075 \\
0.083\end{array}$ & $\begin{array}{l}0.410 \\
0.439\end{array}$ & $\begin{array}{l}2.71 \\
2.25\end{array}$ \\
\hline
\end{tabular}

a) Data in experiments 1 and 2 are the mean $\pm \mathrm{SE}$ and in experiment 3 are the means of pooled samples.

* $\mathrm{P}<0.05$.

Table 7. The ratio of fatty acids of liver mitochondrial phosphatidylcholine, a)

\begin{tabular}{c|ll|c|c|c}
\hline $\begin{array}{c}\text { Expt. } \\
\text { no. }\end{array}$ & \multicolumn{1}{c|}{ Group } & & $16: 1 / 16: 0$ & $18: 1 / 18: 0$ & $20: 4 / 18: 2$ \\
\hline \multirow{4}{*}{1} & Thr deficient & $(4)$ & $0.069 \pm 0.009$ & $0.850 \pm 0.044$ & $\mathbf{0 . 3 4 0 \pm 0 . 0 6 4}$ \\
& Pair & $(4)$ & $0.092 \pm 0.014$ & $0.946 \pm 0.168$ & $0.380 \pm \mathbf{0 . 1 0 4}$ \\
& Ileu deficient & $(4)$ & $0.114 \pm 0.021$ & $0.758 \pm 0.079 *$ & $\mathbf{0 . 5 7 8} \pm \mathbf{0 . 4 8 0}$ \\
& Pair & $(4)$ & $0.166 \pm 0.011$ & $1.060 \pm 0.037$ & $\mathbf{0 . 8 0 3} \mathbf{0 . 1 5 8}$ \\
\hline \multirow{4}{*}{2} & Met deficient & $(4)$ & $0.105 \pm 0.014$ & $0.809 \pm 0.115$ & $1.186 \pm 0.089$ \\
& Pair & $(4)$ & $0.101 \pm 0.014$ & $0.624 \pm 0.027$ & $1.370 \pm 0.095$ \\
& Lys deficient & $(4)$ & $0.109 \pm 0.010$ & $0.542 \pm 0.058$ & $1.808 \pm 0.158$ \\
& Pair & $(4)$ & $0.095 \pm 0.010$ & $0.721 \pm 0.066$ & $1.345 \pm 0.169$ \\
\hline \multirow{6}{*}{3} & Leu deficient & $(3)$ & 0.095 & 0.511 & 1.72 \\
& Pair & $(3)$ & 0.115 & 0.800 & 2.09 \\
& Val deficient & $(3)$ & 0.094 & 0.566 & 2.04 \\
& Pair & $(3)$ & 0.098 & 0.628 & 2.17 \\
& Phe deficient & $(3)$ & 0.093 & 0.601 & 1.37 \\
& Pair & $(2)$ & 0.119 & 0.704 & 2.02 \\
& Trp deficient & $(3)$ & 0.048 & 0.337 & 2.67 \\
& Pair & $(2)$ & 0.088 & 0.544 & 2.31 \\
\hline
\end{tabular}

a) See table 6 .

* $\mathrm{P}<0.05$.

The present study showed that the concentration of liver phospholipid decreased in each EAA deficiency, this being remarkable with PE (see Table 4), which in general contains polyunsaturated acids in the higher percentage compared with PC. Met, Leu or Val (and Phe) deficiency caused the decreases in percentage of arachidonate in liver PC. Viviani et al. (1964) have reported the 
decreases in linoleate, arachidonate and docosahexaenoate in carcass phosholipid of rats fed on the diets deficient in Lys or Thr. In our experiments docosahexaenoate in liver PC increased in rats fed on diets deprived of Thr, Ileu or $\mathrm{Val}$ (and Trp). Arachidonate decreased in Met, Leu or Val (and Phe) deficiency and linoleate increased in Ileu deficiency. The discrepancies may partly be attributable to the difference among the specimens analyzed and partly to that in the pattern and quantity of dietary amino acids.

Innami et al. (1967) have demonstrated that arachidonate, in the form of the esterified fatty acids, in serum from rats deficient in Lys, Met, Trp, His, Phe or Val increased. This was not consistent with the present data on hepatic PC. Moreover, the unpublished data on the phospholipid and cholesterol este fractions in plasma obtained from rats in this experiment does not necessarily agreed with those of the above authors.

The reduction of the concentration of arachidonate and that of the ratio of arachidonate to linoleate in hepatic PC may indicate that 6-desaturation reaction of the acyl moieties is suppressed and the pool size of arachidonate is significantly modified by feeding on the EAA deficient diets. In facts, Inkpen et al. (1669) and Peluffo et al. $(1969,1971)$ have shown that the levels of the dietary protein significantly influence the extent of the desaturation of linoleate. However, the mechanism by which desaturation is influenced by the level as well as the quality of the dietary protein remained obscure. Some of the dietary amino acids directly effect the production and secretion of several hormones (Munro et al., 1963). Administration of estradiol to the rats reduces the quantity of the diene fraction and increases stearate and arachidonate in hepatic PC (Lyman et al., 1963). It is, therefore, presumable that the modification of hormonal balance due to dietary protein malnutrition is partly responsible for the changes in the desaturation reaction. More detailed studies are required for further understanding of this problem.

\section{REFERENCES}

Bragdon, J. H. 1960 Method for determination of total serum lipids. In "Lipid and Steroid Hormones in Clinical Medicine", ed. by Sunderman F. W., Lippincott Press, Philadelphia, pp. 9-14

Folch, J., M. Lees and G. H. Sloan-Staneley 1957 A simple method for the isolation and purification of total lipids from animal tissues. J. Biol. Chem., 226: 497-509

Gomori, G. 1942 A modification of the colorimetric phosphorus determination for use with the photoelectric colorimeter.J.Lab.Clin. Med., 27: 955-960

Hall, K. W., V. P. Sydenstricken, W. McCollum and L. L. Bowles 1952 Accumulation of fat in the liver with deficiencies of threonine and of lysine. Arch. Pathol., 53: 154-159

Hanahan, D. J. and R. Blomstrand 1956 Observations on the incorporation in vivo of palmitic acid-1-14 $\mathrm{C}$ and oleic acid-1-\% into lecithins. J.Biol. Chem., 222: 677-683

Inkpen, C. A., R. A. Harris and F. W. Quackenbush 1969 Differential responses to fasting and subsequent feeding by microsomal systems of rat liver. J. Lipid Res., 10: 277-282

Innami, S., A. Nakamura and T. Tezuka 1967 Serum and adipose tissue fatty acid composition in rats fed on the essential amino acid deficient diets. Annual Rep. Natl. Inst. Nutr. Japan, 9: 24-31

Land, W. E. M. 1958 Metabolism of glycerolipids : A comparison of lecithin and triglyceride 
synthesis. J. Biol. Chem., $231: 883-888$

Lyman, R. L., C. R. Cook and M. A. Williams 1964 Liver lipid accumulation in isoleucinedeficient rats. J. Nutr., 82: 432-438

Lyman, R. L., S. M. Hopkins, G. Sheehan and J. Tinoco 1968 Effects of estradiol and testosterone on the incorporation and distribution of $\left[\mathrm{Me}-{ }^{14} \mathrm{C}\right]$ methionine methyl in rat liver lecithins. Biochim. Biophys. Acta, 152 : 197-207

Maeda, H., M. Sugano and M. Wada 1973 Dietary protein and liver lipids in rats: Effect of the dietary protein levels on liver lipids, Sci. Bull. Pac. Agr. Kyushu Univ., 27: 11-16

Munro, H. N., M. H. Steele and W. C. Hutchison 1963 Blood corticosterone levels in the rat after administration of amino acids. Nature, 199: 1182-1183

Ogura, M., H. Tanaka and A. Ito 1968 Biochemical studies on fatty liver: Changes of fatty acid composition in fatty livers induced by an amino acid imbalance. Agr. Biol. Chem., 32 : $920-922$

Peluffo, R. O., I. N. T. De Gomez Dumm, M. J. T. Alanig and R. R. Brenner 1971 Effect of protein and insulin on linoleic acid desaturation of normal and diabetic rats. J. Nutr., 101: $1075-1083$

Peluffo, R. O., I. N. T. De Gomez Dumm and R. R. Brenner 1972 The activating effect of dietary protein on linoleic acid desaturation. Lipids, 7: 363-367

Rama Rao, P., B. Norton and H. W. Johnson 1961 Amino acid composition and nutritive value of proteins. J. Nutr., 73: 38-46

Rouser, G., A. N. Siakotos and S. Fleisher 1966 Quantitative analysis of phospholipids by thin-layer chromatography and phosphorus analysis of spots. Lipids, 1: 85-86

Schneider, W. C. and G. H. Hogeboom 1950 Intracellular distribution of enzymes: Further studies on the distribution of cytochrome $\mathrm{C}$ in rat liver homogenates. J. Biof. Chem., 183: $123-128$

Sidransky, H. and E. Farber 1958 Chemical pathology of acute amino acid deficiencies: Biochemical changes in rats fed threonine or methionine devoid diets. Arch. Pathol., 66: 135-149

Sidransky, H. and E. Virney 1964 Chemical pathology of acute amino acid deficiencies : Morphological and biochemical changes in young rats force-fed arginine-, leucine-, isoleucine-, or phenylalanine-devoid diets. Arch. Pathol., 78 : 134-148

Sperry, W. M. and M. Webb 1950 A revision of the Shoenheimer-Sperry method for cholesterol determination. J. Biol. Chem., 187: 97-106

Sugano, M., K. Imaizumi, S. Cho, K. Hori and M. Wada 1969 Hepatotoxicity and lipid metabolism : Structure of liver triglyceride in rats dosed with carbon tetrachloride. Biochem.

Pharmacol., 18 : 1961-1970

Viviani, R., A. M. Sechi and G. Leuaz 1964 Effect of lysine and threonine deficiency on the fatty acid composition of carcass lipids in the rat. Biochim. Biophys. Acta, 81: 201-204

Wilfred, G. and T. N. Sekhara 1969 The mechanism of hepatic fatty infiltration in acute threonine deficiency. Biochim. Biophys. Acta, 187: 442-443

Yoshida, A., and A. E. Harper 1960 Effect of threonine and choline deficiencies on the metabolism of ${ }^{14} \mathrm{C}$-labeled acetate and palmitate in the intact rat. J. Biol. Chem., 235: 25862589 